\title{
Gender Domination in Nigerian Public Relations
}

\author{
Bonachristus Umeogu ${ }^{1}$, Ojiakor Ifeoma ${ }^{2}$ \\ ${ }^{1}$ Department of Philosophy, Faculty of Arts, Nnamdi Azikiwe University, Awka, Nigeria \\ ${ }^{2}$ Department of Mass Communication, Faculty of Social Sciences, Nnamdi Azikiwe University, Awka, Nigeria \\ Email: \{bonaumeogu, ojiakor99\}@yahoo.com
}

Received April 1 ${ }^{\text {st }}$, 2012; revised April 5 ${ }^{\text {th }}$, 2012; accepted April 19 ${ }^{\text {th }}, 2012$

\begin{abstract}
Does gender influence practice? This paper using the theory of agenda setting and constructionist theory of representation assesses the public relations profession in relation to the value, treatment and power accorded to the different gender in the course of their professional duties. It was found out that even though there are fewer men in number, the males have more power than their female counterparts. Also, gender, directly or indirectly influence treatment and value. This paper is highly significant in the face of the global call for equal playing ground for both male and female in all spheres of life.
\end{abstract}

Keywords: Gender; Treatment; Value; Power

\section{Introduction}

There are important developments of public relation in the twentieth century. Among them are the growth, recognition and acceptance of public relations as a vital communication link in addition to, ascending the status of being a useful tool in the hands of the government and all organizational managers in the modern States. Again, research in PR effects have revealed that the corporate image and identity of every organization is a determinant to how its publics perceive the organization: and gaining and keeping the support and cooperation of others through perception is part of the day to day business of every organization whatsoever.

This demonstrates that every organization be it government, business, firms, labour unions, universities, non-governmental and service organizations and even private firms has need for PR whether as an in-house or outside services. Yet, this noble profession has however attracted a lot of misinterpretation and misconceptions. Some of such misconceptions are that PR is an all comers affair; gender dominated: is all about publicity stunt: mainly for unserious minds: and is "corporate prostitution" especially for the female gender. That notwithstanding, the thrust of this paper is to analysis if PR is really gender dominated. However, if the answer to the question of PR being gender dominated is in the affirmative, which of the gender dominates and the resultant effect.

The analysis will look at the philosophical treatment: value and power since they are among the aspects of the gender balance in public relations. It is even more surprising that PR which is about image making is riddled with this kind of conceptions or misconceptions as the case may be. They build images and good relations for their clients and yet, as professionals have one of the worst images of an occupation not to mention a profession.

In a nutshell, this paper amongst other things principally aims to determine the gender distribution in PR practice in Anambra State of Nigeria; assess the general perception of men and women in PR; and establish whether there is a co-relationship between the understanding of PR in Nigeria as image making or glamour and the gender distribution of PR practice.
But first we have to understand the meaning of the word "gender domination”.

\section{Quick View at the Meaning of Gender Domination}

What is meant by gender domination? According to Idiyorough (2005), it

\begin{abstract}
Means possession and control of power and authority and the use of such possession against another person. Domination as a gender issue in a patriarchal society is a situation where men are in possession of power and authority and they use these to control women to the benefits of men. It is a situation of complete subjugation and oppression of women in the economic production and reproduction of children where men have controlling power and authority. Domination in patriarchal societies include; the power to control women's bodies, that is the power to control women's sexuality.
\end{abstract}

In as much as I agree with Idiyorough's explanation of gender, I want to point out that the domination does not always have to be on the male side. There are various shades of domination. There is domination by power, number, influence, privileges, control etc. There are cases where the female dominate especially in numbers. This shows that it is not the privilege of the male sex only but male domination is more significant. Also, it seems to be more significant because of the way the media portray patriarchy and the stereotyped notion that women are naturally created to be subordinate to men. However, in this concept, gender domination tends to look at the position and roles of the males and females in relation to the practice of public relations in Nigeria.

What is the consequence of gender domination? As long as there is domination, the resultant effect is discrimination. According to Idiyorough (2005) "gender discrimination often exists where there is different treatment of individuals on the grounds of their gender. The nature of discrimination may be personal or systematically and structurally created for example, deter- 
mination of income, access to housing facilities...” About having access to housing facilities, I remember the story of a lady who almost lost her accommodation because she was single and the landlord almost denied her the flat if not that she lied that she was engaged to a man who stays outside the country. Do the men experience that kind of treatment? I guess not. The landlord will feel more comfortable with a bachelor to a spinster. It is that bad!

\section{Research Methodology}

This paper will use the sample survey method. Sample survey entails an investigation where only part of the research population is studied such that the sample is representative of the whole population (Stacks \& Hocking, 1999). This involves going to Zenith, ETB, UBA and Spring banks. In addition, Expressor Consultancy Firm, Fegge Police Station, Nwafor Orizu College of Education and Nnamdi Azikiwe University, Awka all in Anambra State were all consulted through in-depth interviews. Their views were combined with books on public relations and documentaries of several authors on gendered profession.

\section{Theoretical Foundation/Literature Review}

This paper will be anchored on two theories namely; the agenda setting theory and the constructionist theory of representation. In the course of this research, it was gathered that there are more females than males. This resulted in choosing the agenda setting theory to look at how the misconceptions/ conceptions came about in the first place and how the representation of both sexes are constructed, since the concepts is a product of the society's construction ability.

Agenda setting theory can be said to have begun with Lipmann (1972) who maintained that the media are responsible for putting pictures in our heads. Cohen (1963) in Ukwueze (2008) went further to argue that the "media may not always be successful in telling people what to think, but they are usually successful in telling people what to think about”.

Agenda setting theory recognizes that the media are very powerful when it comes to constructing social reality. This demonstrates the power and ability of the media to determine the way people, events and issues are perceived in a society. This can be as a result of the fact that it is an information age where the mass media provide a significant percentage of the information and ideas that the people require for comprehension of happenings around them.

Lipmann (1972) stated that the media help to "put pictures in our heads". This statement which was made about three decades ago is still very relevant in this present dispensation. What is obtainable in the world outside might not be in consonance with the pictures in our heads. What is really obtainable in PR profession often times are in dissonance with the pictures the media fill our heads with. No wonder Daramola (2003: p. 20) posits that "there is a relationship between news coverage and public perception of the importance of the issue. The media may not be successful in telling us what to think but are stunningly successful in telling us what to think about”. In this case they are equally successful in telling us what to think about public relations practice.

This theory posits that it is how the media present men and women that the world or audience would see them. Many peo- ple cannot define PR or have been to a PR unit or consultancy firm yet they supposedly can give a picture of what goes down in those firms. How do they manage to get those mental pictures? The answer is simply through the media. Another example of the power of the media is the image of Nigerians abroad. To a white, the name Nigerian simply means "beware” because here is the embodiment of evil. They are known as dishonest, primitive, robbers, ritualists etc. All these are not true of every Nigerian or even a few Nigerians but thanks to negative reporting, that is the picture the whites have of Nigerians.

The problem of PR is the bad image created mostly by the media. If only the media employing their agenda setting power could change their contents about PR and even Banks, the public will begin to see them in a different light and will eventually learn to appreciate the profession and its professionals. This can be systematically done through home movies, drama, features, commentaries and documentaries.

Also writing on agenda setting, Okunna (2003) explains that "given the powerful role of the mass media in determining our perception of social reality, media presentations of people and issues have always been a subject of interest".

Understandably, the issue of presentation especially women in the media has been a long standing gender problem in mass communication.

The media have been accused of presenting men and women in stereotyped and negative ways that help to keep the women in a position of powerlessness. Stereotype here means inaccurate and negative generalizations about group or individual members, which may be used to justify certain discriminatory behaviours. Research has also proven that what the media say or fail to say determines how such people are perceived in the society. In Nigeria, the home videos are/is filled with stereotype images of women which have generated negative perception of Nigerian women especially professionally.

In the course of this research, it was found out that there is less number of men than women in public relations. Also, in an attempt to establish a causal relation between the agenda setting function of the mass media and the few presence of men in public relations, I came to the conclusion that whatever is obtainable in the larger society always have a bearing to the media. How did we come to label engineering as a masculine profession? How did we come to the conclusion that customer service relation is a feminine line? How did we ever imagine that pubic relations employ more women for aesthetics? If I am to answer, all the questions have one answer and it is through the mass media.

Public relation is a profession where both male and female has the innate potentials to excel if provided an equal playing ground. Through the media and its contents, I believe that many men are discouraged from entering the feminized profession thereby leading to the decline in the masculine presence in the public relations room.

The second theory is the constructionist theory of representation. This theory which was made popular by Hall (2000) posits that meaning is a construction. According to Hall, meaning is constructed by the individual users of language. Things don't mean: we construct meaning using representational systems of concepts and signs. The translatability is not given by nature or fixed by the gods rather it is a result of a set of social conventions. It is defined socially, fixed in culture. This particular theory is all about visual communication. If a picture or image that we construct is worth a thousand words, then we will un- 
derstand the relationship of this theory to this research work. The main point is that meaning does not inhere in things but is constructed and produced as a result of signifying practices.

This theory acknowledges that men and women are involved in constructing their own gendered identities. How do I mean? Cooper 1998 in Ojiakor (2010) notes that our understanding of gender is dynamic, changing overtime with maturity, experience and reflection. Who made the change in understanding? It is either a man or a woman which means that it is not the gods that apportion gender roles. Let me give an example, Sean Nixon 2000 in Ojiakor (2010) researched on men and masculinity and found out something interesting. Before now, childcare has been the sole gender role of femininity but he found adverts of a man cuddling a baby which was a first. This means that the age long notion of women and babies are changing. Who initiated that perception change? In my opinion, it might be the advertising agency who wanted to come up with a campaign that is relatively new. This goes a long way to show that human beings are active in constructing their gendered identities.

This theory is also related to this study as a result of the fact that gender domination and its other half discrimination is a product of social construction. Writing on this, Idiyorough (2005) posits that

\section{"Gender discrimination is socially constructed. That is to say the process of thinking, feeling and acting towards women negatively or positively is conceived and socially expressed and maintained within the home/family, the peer group, the community, the workplace, the school, the worship centre, and the political arena".}

He went on to explain why gender discrimination is a social construction by writing that

"Gender roles are socially learned within the family, the peer group, the work place, the worship centre, and the political arena. Learning of gender roles takes place within the family; where mother/wife, father/husband, son/ daughter, boy/girl roles are acquired through socializetion and re-socialization. This is the process by which gender is socially constructed in Nigeria”.

\section{A Quick Look at Public Relations}

One of the fathers of public relations Edward Bernay quoted in www.wikipedia.org/history saw public relations as an applied social science that uses insights from psychology, sociology, and other disciplines to scientifically manage and manipulate the thinking and behavior of an irrational and "herd like" public.

The summary of what PR is all about is that it is mind management without misinforming or disinforming the public. This point is also buttressed by Bernay when he wrote that "the conscious and intelligent manipulation of the organized habits and opinions of the masses is an important element in democratic society".

A writer at www.newworldencyclopedia.org went a step further by defining and explaining PR thus:

Public relations $(P R)$ is the art of managing communication between an organization and its key publics to build, manage, and sustain a positive image. Public relations involves evaluation of public attitudes and public opinions; formulation and implementation of an organization's procedures and policy regarding communication with its publics; coordination of communications programs; developing rapport and good-will through a two way communication process; and fostering a positive relationship between an organization and its public constituents. Public relations often involve news management-optimizing good news and forestalling bad news. Equally, good public relations managers conduct "damage control" when a disaster occurs, gathering the facts and assessing the situation to prepare appropriate information to be offered to the mass media.

That was a lengthy quote but it was able to sum up the basics of Public Relations and its practice.

\section{PR and Gender}

Gender! Gender!! Gender!!! When we say gender, our mind usually goes to women alone, but gender and its resultant issues involve both men and women and the power relations between them.

Robinson (2005) writes that gender matters in research and everyday life which means that gender does not only play a crucial role in everyday life, but also the ways in which culture and language affect professional behaviour. It has been said by gender scholars that every person has two simultaneous version of self which includes an inner private sexual identity and the outer social and public gender identity. While the former is determined by genes and biology, the latter is defined by the society. According to Reeves and Basden (2000),

Gender is how a person's biology is culturally valued and interpreted into locally accepted ideas of what it is to be a woman or man.

This reveals that gender however is not the fixed attribute of an individual, but is "socially constructed" through cultural norm that spells out in codes women's "proper role" in the society. Gender focuses on both women and men and on the relationship between them. That is, it highly acknowledges that gender and what it stands for are socially constructed rather than being determined by biology. It is not about being a male or female but, what being a male or female entails.

General usage of the term 'Gender" began in the late 1960s and 1970s, increasingly appearing in the professional literature of the social sciences. The term came to serve a useful purpose in distinguishing those aspects of life that are most easily attributed or understood to be of social rather than biological origin (Unger \& Crawford 1992 in Diamond, 2000).

Coming to PR and gender proper, research in 1973 previous findings as was gathered in the course of this research, revealed that there were more males than female practitioners. Today however, female practitioners outnumber the males. Recent statistics shows that there is now female gender domination in PR. A look at some banks, consultancy firms and two higher institutions by this researcher confirms this claim.

Macdonald (2007) outlines the following reasons as why there are more females than male in PR.

- Women are better communicators than men;

- PR pays better than any other female dominated field.

I don' $\mathrm{t}$ know if that is applicable in Nigeria, so there is a need for a comparative study to ascertain if this claim is uni- 
versal or country specific.

- Women find PR more welcoming than other business discipline.

Take a look at most mass communication department in Nigerian universities; there are always more females to men. I also believe that this domination in the department by number accounts for the number domination in the field.

- While women are in the Arts, the men are pushed to the sciences.

At this point, also take a look at the engineering faculties and departments of our higher institutions. While the men dominates in engineering, the females call the shots in the arts and humanities.

From the above, we can now understand why Grung (2001) asked,

Can PR become a professional where individual talents are perceived independently of gender because no thoughtful discussion of the $P R$ industry can proceed without examining the feminization of the work force.

\section{Gender Domination Analysis}

From time immemorial, researchers have always strived to understand gender based differences in pay packets, unequal access to health, education, insurance promotion rates and the leadership structure in the top communication role. However, this paper will assess the value, power and treatment since they are among the aspects of gender balance argument.

\section{Unequal Power}

How much power do men and women wield in an organization? Robinson (2005) writes that

Women's work is systematically structured by gender and these biases are imported into organizational struc- tures. This importation is not innocent but negatively af- fects the way in which females are able to wield power in the organizational setting.

Position automatically goes with power with means that the higher you go, the more power that you will possess. In other words, the status of one determines the power. Status can be defined according to Robinson (2005) as either professional through the kind of job you do or hierarchically through the position one occupies in the organization. In her research, she found out that women are found in the middle, and this automatically affects the power they wield. This is in consonance with this researchers finding because all the firms and organization have men at the top where they make all the decisions thereby maintaining their patriarchy. When it comes to relationship and power, the both sexes seem to be on equal par, but when it is structural, the scale tilt towards the males. Why? This research wanted to find out from the field the reason for this situation. This is what Idiyorough (2005) meant by gender stratification and addressed it by commenting that

Gender stratification refers to the various layers that exist between men and women in their access to privileges, prestige, power and authority. Generally, it is men that occupy higher layers in access to privileges, prestige, power and authority available in the society. It is the men that decide what, when and how. It always exists where

\section{there is patriarchy, discrimination and gender gap.}

The practitioners couldn't explain why mostly the men are at the top. This does not mean that there are no females occupying management position. At the time of this research, a woman is the Head of Service at Zenith bank; and the Assistant Head of Service at ETB. At spring bank, it was revealed that there is no permanent person for the post but subject to productivity following appraisal. The fact is that their number is insignificant as against that of the men. It was gathered that a "good" performance might elevate one to human resources manager.

How is good performance measured? Is it in the number of years in the organization as in years of experience or in production outputs as in clients' portfolio? There seemed to be a general conspiracy not to divulge reasons but a fleeting glance revealed that the top position saw men who looked older. Does it mean they have been in the system long before the women came on board? Does it account for the difference in the power wielded? I think it calls for more research to answer the unanswered questions.

\section{Inequality of Value}

What is value? How can value be measured? What professional cadres do women occupy in the sampled organizations? Well, when it comes to number, the ratio of female to males was about 7:3. I think that pay packet and position are major determinants in proving worth and value. Even though there are more females, men continue to hold proportionately more of the managerial PR posts. This might account for the salary difference which is one of the gender issues of concern. Salary depend on status in the organization a staff at level nine cannot have the same figures as another in level four. It is all about the levels and the cadres. Your position determines your pay packet.

Are the women bothered? Well, most of them are happy that they have been able to break out from the shackles of housewife role and femininity where society relegated them. There was a time when it was unheard of to be working in a corporate environment; when women took pride in being housewives. Well, gone are those days.

Addressing this issue, Betty Freidan's the feminine mystique (1963) criticized the idea that women could only find fulfillment through childbearing and home making. She hypothesizes that through no fault of theirs, women are victims of as false belief system that requires them to find identity, purpose, meaning and satisfaction in their lives through their husbands and children. This according to her has made women's work less meaningful and less valuable.

Do the so called practitioners even know what public relation entails? At the two institutions visited, the PR department was filled with staff mostly women (surprisingly, they were advanced in age too) while the PRO were male. According to the women when asked about their job functions, it entails keeping records, gathering information for the schools periodicals and other menial jobs that have nothing to do with PR. The researcher learnt that they were not asked to go for marketing or scout for clients accounts. According to one interviewee, "we are just here for writing and clerical purposes”.

A point worthy of note is that what we have at the banks and consultancy firms were different altogether with the higher institutions. Others have younger staff while advanced women were mostly in the higher institution. To answer the question of 
if they really understands their job specification, the answer is no. I think that they confuse PR department with Information office. At the only police Station visited, it has a PRO with no clear cut PR department. However, it was gathered that a functional PR department is at the State headquarters. It was also learnt that the major job specification of the PRO is to make public the stand of the commission or comment on case(s) that attract public attention.

With the revelation that most of the staff had no idea of what public relations is in the first place, the researcher came to understand the genesis of the conception that Public Relations is an all comers affair. It was further gathered that the reason for this is that of scarcity of jobs. One is considered lucky to have gotten one despite that name it is called as long as it pays the bill at the end of the month. Also, they go for intra transfer, that is, one might be transferred from the marketing unit to human resources or operations as the need arises.

\section{Unequal Treatment}

In every rumour, there must be an atom of truth; just like the old saying that there can never be smoke without fire. What am I trying to say? This can be said to be the case of gender treatment all in the name of public relations. Yes, the media portrays women in the corporate circle generally as corporate prostitutes and are used as baits to lure customers. In few cases, they are given as gratification to big time customers to retain them. This claim is not unfounded. According to a staff at one of the so called new generation banks, she pointed out that the managers know the willing ones and are used for such.

For some others, they can aid their promotion through special benefits. It all boils down to survival of the fittest. Another from another organization (speaking from a personal experience) revealed that the way one comports herself/himself influences how you are perceived. Being used as a bait or "thank you" is a personal thing because some women actually crave for it because they see it as the fastest way of climbing the ladder. Others who are not game will mildly refuse but will make up by working extra hard. That is probably why they have not been relieved of their duties. To the question of sexual harassment, the response was that it is all about carriage and comportment.

Why do they always employ fine ladies and gents? Does outward beauty equate intelligence to smartness? A managing director at a PR consultancy firm was of the opinion that every organization need clients, customers and accounts to survive and they therefore employ sharp women to attract customers because it is believed that the big customers are mostly men, and there is a predominant stereotype that men have "light brain" when it comes to pretty women. The same happens with women and handsome gentlemen. Writing on stereotype, Pickering (2001) explains that

What remains crucial to the critique of stereotype is not only the question of who speaks for whom and with what consequences, but also how stereotype relate to conceptions of what is held to be "natural" or "normal", how they create and sustain common sense of the proper limits of what is accepted as legitimate and right.

This insight could be the reason why female PR in specific and practitioners' in general are misconstrued negatively. Here, it all boils down again to world outside and pictures in our heads. Are the pictures real, and to what extent?

On how he treats the female members of his staff, he responded that he respects them as long as they justify their salaries. It was more like "do what you have to do, it is your life". A bank manager actually said that if you can sleep with a man for pleasure; what then is the difference between that and doing it for business gains. After all, the end justifies the means.

\section{Recommendations/Conclusion}

Morrisey in Eluwa (1999) is of the opinion that PR has the worst image of any occupation let alone profession. Since it all boils down to image problem, this paper recommends re orienttation of the public as a whole. This cannot be remedied by the media alone. All hands must be on deck. The practitioners on their part since their job involves media relations should maximize the media to their advantage and change the stereotyped images of the public. The causes of these stereotypes and misconceptions in some cases are rooted in our social structures. It is within the power of the media to stimulate the desired change through embracing positivity.

Furthermore, people are greatly influenced positively or negatively by what they see; and what they see is what they believe. What I am trying to say is that the pictures in the heads of most people are negative about females in PR and bankers in general. This is because they believe that at some point, they cut corners to be on track. After all, the media try to reflect the patterns of our daily life. In other words, most of what we see is true. The practitioners have to conduct themselves in a classy manner to be true to its name. Above all, this paper recommends $n$ equal playing ground for both sexes. That is, equality at work, value, power, treatment and control over resources.

On a conclusive note, does gender influence practice? Does the fact that PR is a gendered profession change anything? The answer is that if the people are matured about it, it does not change anything. This is because while the women dominate in number, the men dominate in power and so on and so forth. Male or female, boy and girl are all blessed with unique talents that will make the world a better place. One cannot do without the other so why the hassle. Let both sexes know their boundaries and co exist and complement so as to maximize one another's potentials. I want to close with the words of Ingrid Tharasook who wrote that "I don't mind living in a man's world as long as I can be a woman in it"; and ipso facto, it must also be said, by function of the male gender: "I don't mind living in a woman's world as long as I can be a man in it”. The problem is that in many a man's world, women have been made men; and in many a woman's world, men have been made women. That should not be so. For, "he who made them from the beginning made the male and the female".

\section{REFERENCES}

Baran, S. (2004). Introduction to mass communication. New York, NY: McGraw Hills Companies.

Benson-Eluwa, V. (1999). PR: A practical approach. Enugu: Virgin Creations.

Daramola, L. (2003). Introduction to mass communication. Lagos: Ruthan Press Ltd.

Diamond, M. (2000). Sex and gender: Same or different? Feminism and Psychology Journal, 1, 40-54.

Grung, L. (2001). Women in PR: How gender influence practice. New York, NY: Guilford Press. 


\section{B. UMEOGU, O. IFEOMA}

Hanson, R. (2005). Mass communication in a media world. New York, NY: McGraw Hills Companies.

Idiyorough, A. (2005). Gender: Concepts and issues in Nigeria. Makurdi: Aboki Publishers.

Jefkins, F. (1984). Intro to marketing, advertising and PR. Hong Kong: Macmillan Publishers.

Lattimore et al. (2005). PR: The profession and the practice. New York: McGraw Hill Companies.

Lipmann, W. (1979). World outside and pictures in our heads. In W. Schramm, \& D. Roberts (Eds), Process and effects of mass communication (pp. 3-39). Urbana, IL: Urbana University Press.

McAllister, L., \& Dudau, A. (2006). Gender based barriers to effective collaboration: A case study on children's safeguard partnership. International Journal of Human and Social Sciences, 2, 809-812.

Mcquail, D. (2005). Mass communication theory (15th ed.). Thousand

\section{Internet Sources}

Commission on the Status of women available at www.un/org/new/doc assessed on 13/01/2011.

Feminism available at www.wikipedia.org/wiki/femininism assessed on 13/01/2011.

Gender definitions at www.bridge.ids.ac assessed on 02/12/2011.

History of public Relations at www.wikipedia.org/wiki/history retrieved on $02 / 12 / 201$.
Oaks, CA: Sage Publishers.

Okafor, G. (2002). Teaching mass communication. Enugu: New Generation Books.

Okunna, C. (2003). Women and the media. International Journal of Social Inquiry, 1.

Onabanjo, O. (2002). Essentials of media law and ethics. Lagos: Gabi Concepts.

Reeves, H., \& Baden, S. (2000). Gender on development: Concepts and definitions. Falmer: University of Sussex.

Robinson, G. (2005). Gender, journalism and equity. Cresskill, NJ: Hampton Press Inc.

Stacks, D., \& Hocking, F. (1999). Communication research (2nd ed.). New York, NY: Longman Publishers.

Unites Nations (2005). MDG reports.

\section{Public relations at}

www.newworldencyclopedia.org/entry/public_relations assessed on $04 / 12 / 2011$

\section{Other Sources}

Ojiakor, I. (2010). A study of gender representation in billboard advertisements. Awka: Nnamdi Azikiwe University. 